\title{
Simultaneous Third order derivative Spectrophotometric Determination of Vanadium and Palladium Using 2-Hydroxy-1-Naphthaldehyde-P-hydroxy Benzoichydrazone (HNHBH)
}

\author{
P. Govinda Chowdary ${ }^{1}$, V. Saleem Basha ${ }^{2 *}$ and V.S.Anusuya Devi ${ }^{3}$ \\ ${ }^{I}$ (Department of Chemistry, Vignan Institute of Technology and Sciences, Deshmuki, Nalgonda, Telangana) \\ ${ }_{2}^{2}$ (Department of Chemistry, Govt, College (UG \&PG), Autonomous, Anantapur, A.P, INDIA. 515001) \\ ${ }_{3}^{3}$ (Department of Chemistry, New Horizon College of Engineering, Marathahalli, Bangalore
}

\begin{abstract}
A highly sensitive and selective third order derivative spectrophotometric method is proposed for the simultaneous determination of Vanadium and palladium. $V(V)$ and $P d(I I)$ react with the Chromogenic reagent 2-hydroxy-1-naphthaldehyde-p-hydroxybenzoichydrazone (HNHBH) at $\mathrm{pH} 4$ to form deep yellow and greenish yellow coloured solutions with $\lambda_{\max }$ at $430 \mathrm{~nm}$. Both the metal ions were simultaneously determined by measuring the third derivative amplitudes at $465.5 \mathrm{~nm}$ and $482.5 \mathrm{~nm}$ (zero cross method) against the reagent blank and plotting against the amount of the corresponding metal ion. Beer's law was obeyed in the range 0.050

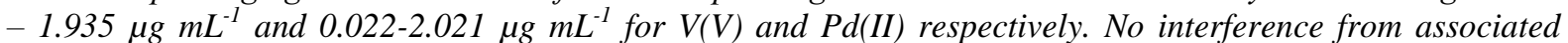
anions and cations was observed. The method was applied for the determination of $V(V)$ and Pd (II) in plant, pharmaceutical, water and alloy samples.
\end{abstract}

Keywords: Simultaneous determination, Third order spectrophotometry, Vanadium and Palladium, HNHBH

\section{Introduction}

Vanadium and Palladium are chemically and industrially important as Vanadium is an important component of ferrous alloys used in jet-aircraft engines and in turbine blades and Palladium is used in instrument making [1], in aircraft spark plugs and in the production of surgical instruments and as electrical contacts.

On the other hand Vanadium compounds are toxic to human beings and animals. They inhibit biosynthesis of cholesterol in mammals, present in human blood and plasma [2] (in the range 0.005-8.4 $\mu \mathrm{M}$ ). Its poisoning is treated as an industrial hazard [3], air pollutant,[4] which causes nervous depression, vomiting, coughing, anemia, diarrhea and increased risk of lung cancer, that are sometimes fatal. [5-6] and Palladium is thought to be one of the allergent in view of health hazards[7] so it is an important research activity for a analytical and bio-analytical chemist to determine vanadium [8] and palladium [9] in trace levels or ultra trace levels. Review of literature reveals that simultaneous spectrophotmetric determination of V (V) and Pd (II) are not exploited so far, so we are now proposing third derivative spectrophotometric method for the simultaneous determination of $\mathrm{V}(\mathrm{V})$ and Pd (II) by zero cross method without the need for solving simultaneous equations.

\section{Experimental}

\section{Materials And Methods}

The absorbance and $\mathrm{pH}$ measurements were made on a Shimadzu UV-visible spectrophotometer (Model UV -160A) fitted with $1 \mathrm{~cm}$ Quartz cells and ELICO digital $\mathrm{pH}$ meter model LI - 120 respectively. The $\mathrm{pH}$ meter has temperature compensate arrangement and has reproducibility of measurement within $\pm 0.01 \mathrm{pH}$.

\section{Reagent and solutions}

All chemicals used were of analytical-reagent grade of the highest purity available procured from Merck. Doubly distilled de-ionized water was used throughout the experiment. Glass vessels were cleaned soaking in acidified solutions of $\mathrm{K}_{2} \mathrm{Cr}_{2} \mathrm{O}_{7}$ followed by washing with conc. $\mathrm{HNO}_{3}$ and were rinsed several times with high purity deionized water.

\subsection{Preparation of 2-Hydroxy-1-naphthaldehyde-p-hydroxybenzoichydrazone (HNAHBH)}

The reagent (HNHBH) was prepared by simple condensation of 1 mol of 2-hydroxy-1-naphthaldehyde and $1 \mathrm{~mol}$ of p-hydroxybenzoichydrazide. In a 250-ml Erlenmeyer flask, a hot ethanolic solution of 2-hydroxy1-naphthaldehyde ( $5 \mathrm{ml}, 0.0438 \mathrm{~mol}$ in $5 \mathrm{ml}$ of ethanol), thiosemicarbazide $(4 \mathrm{~g}, 0.0438 \mathrm{~mol}$, dissolved in $10 \mathrm{ml}$ of hot water) were taken in $250-\mathrm{ml}$ round bottom flask. Suitable quantity $(\sim 2 \mathrm{ml})$ of glacial acetic acid was added 
to the reaction mixture and refluxed for 3 hours. [10] On cooling the reaction mixture, the reddish brown coloured solid obtained was then separated by filtration, washed and dried. The product was recrystallized from aqueous ethanol in the presence of norit and dried in vасиио, yield 4.2 g; m.p. $273^{\circ} \mathrm{c}$ as shown in Scheme 1

\subsection{HNHBH solution}

The reagent solution $(0.01 \mathrm{M})$ was prepared by dissolving $31 \mathrm{mg}$ of the compound in dimethylformamide (DMF) in 25-ml standard flask. The reagent solution is stable for at least $12 \mathrm{~h}$.

\subsection{Vanadium (V) solution}

$0.1219 \mathrm{~g}$ of ammonium meta vanadate $\left(\mathrm{NH}_{4} \mathrm{VO}_{3}\right)$ (AR Qualigens) was dissolved in hot distilled water and the solution was made up to $100 \mathrm{ml}$ in a volumetric flask after cooling with distilled water. The stock solution was standardized titrimetrically $[11,12]$.

\subsection{Palladium (II) solution}

A $0.01 \mathrm{M}$ solution of palladium (II) was prepared by dissolving $0.1774 \mathrm{~g}$ of palladium chloride (SigmaAldrich) in minimum volume of $2 \mathrm{~N}$ hydrochloric acid and diluting to $100 \mathrm{ml}$ with distilled water in a $100 \mathrm{ml}$ volumetric flask. This stock solution was standardized gravimetrically using dimethyl glyoxime. Solutions of lower concentrations were prepared freshly by diluting the stock solution to carry out the analysis.

\subsection{Buffer solutions}

Buffer solutions of various $\mathrm{pH}$ values were prepared by mixing $1 \mathrm{M} \mathrm{HCl}$ and $1 \mathrm{M}$ of $\mathrm{CH}_{3} \mathrm{COONa}(\mathrm{pH}$ 1.0-3.0), 0.2 $\mathrm{M} \mathrm{CH}_{3} \mathrm{COOH}$ and 0.2 $\mathrm{M} \mathrm{CH}_{3} \mathrm{COONa}$ (pH 3.5-7.0), 0.2 $\mathrm{M} \mathrm{CH}_{3} \mathrm{COOH}$ and $0.1 \mathrm{M} \mathrm{CH}_{3} \mathrm{COONa}(\mathrm{pH}$ 7.0) and $2 \mathrm{M} \mathrm{NH}_{4} \mathrm{Cl}$ and $2 \mathrm{M} \mathrm{NH}_{4} \mathrm{OH}$ (pH8.0-10.0) solutions in appropriate ratios. The $\mathrm{pH}$ of the solutions was checked with $\mathrm{pH}$ meter.

\subsection{Procedure}

1.6.1. Determination of $\mathrm{V}(\mathrm{V})$ and $\mathrm{Pd}(\mathrm{II})$ in binary mixtures

To different aliquots containing $\mathrm{V}(\mathrm{V})$ and $\mathrm{Pd}(\mathrm{II})$ in variable proportions in $10 \mathrm{ml}$ volumetric flasks, 4 $\mathrm{ml}$ of buffer solution ( $\mathrm{pH} 4.0), 0.5 \mathrm{ml}$ of $1 \%$ triton X-100 and $0.4 \mathrm{ml}$ of HNHBH $\left(1 \times 10^{-2} \mathrm{M}\right)$ were added to each flask and made upto the mark with distilled water. The third order derivative spectra were recorded in the wave length range of 350-600 $\mathrm{nm}$ and the derivative amplitudes were measured at $465.5 \mathrm{~nm}$ and $482.5 \mathrm{~nm}$. The amounts of $\mathrm{V}(\mathrm{V})$ and $\mathrm{Pd}(\mathrm{II})$ present in the binary mixtures were calculated from the measured derivative amplitudes with the help of pre-determined calibration plots("Fig"1 \& 2). The results obtained are shown in Table .1. 


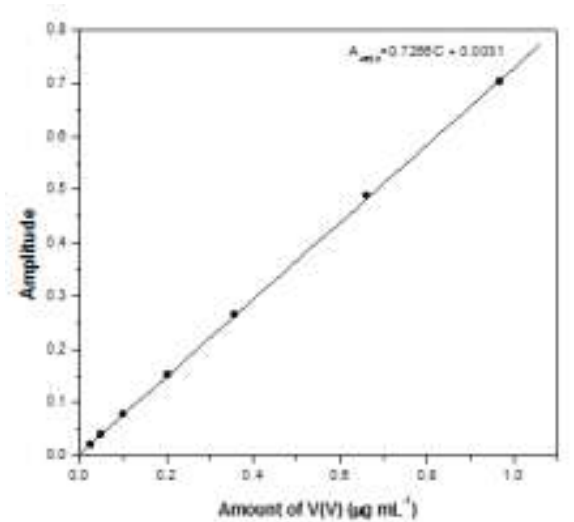

Fig. 1. Calibration plot of $[\mathrm{V}(\mathrm{V})-\mathrm{HNAHBH}]$

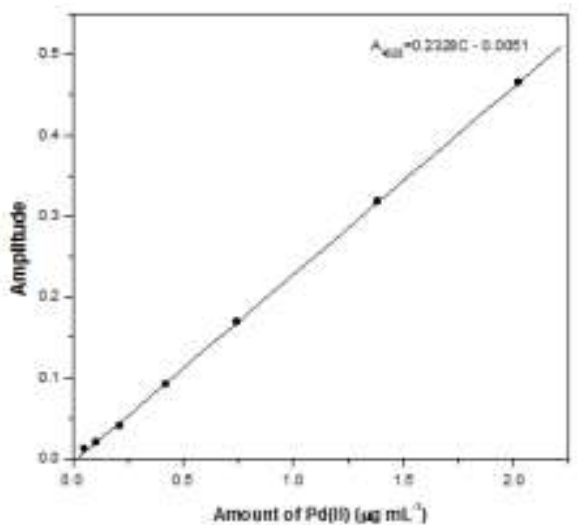

Fig.2. Calibration plot of [Pd(II) - HNAHBH]

Table. 1 Simultaneous third derivative spectrophotometric determination of V (V) and Pd(II)

\begin{tabular}{|c|c|c|c|c|c|}
\hline \multicolumn{2}{|c|}{ Amount taken $\left(\mu \mathrm{g} \mathrm{mL}^{-1}\right)$} & \multicolumn{2}{|c|}{$\begin{array}{l}\text { Amount found }\left(\mu \mathrm{g} \mathrm{mL}^{-1}\right) \\
(\% \text { of recovery) }\end{array}$} & \multicolumn{2}{|c|}{ Relative error (\%) } \\
\hline $\mathbf{V}(\mathbf{V})$ & Pd(II) & $\mathbf{V}(\mathbf{V})$ & Pd(II) & $\mathbf{V}(\mathbf{V})$ & Pd(II) \\
\hline 0.101 & 1.277 & $0.100(99.01)$ & $1.260(98.67)$ & -0.99 & -1.33 \\
\hline 0.203 & 1.277 & $0.207(101.97)$ & $1.302(101.96)$ & +1.97 & +1.95 \\
\hline 0.305 & 1.277 & $0.300(98.36)$ & $1.260(98.67)$ & -1.64 & -1.33 \\
\hline 0.610 & 1.277 & $0.618(101.31)$ & $1.294(101.33)$ & +1.31 & +1.33 \\
\hline 0.814 & 1.277 & $0.810(99.51)$ & $1.270(99.57)$ & -0.49 & -0.55 \\
\hline 0.305 & 0.053 & $0.300(98.36)$ & $0.052(98.11)$ & -1.70 & -1.88 \\
\hline 0.305 & 0.106 & $0.308(100.98)$ & $0.107(100.94)$ & +1.01 & +0.94 \\
\hline 0.305 & 0.212 & $0.305(100.00)$ & $0.211(99.53)$ & -0.26 & -0.47 \\
\hline 0.305 & 0.425 & $0.306(100.33)$ & $0.426(100.23)$ & +0.19 & +0.23 \\
\hline 0.305 & 0.851 & $0.305(100.00)$ & $0.849(99.57)$ & -0.13 & -0.23 \\
\hline 0.305 & 1.064 & $0.306(100.33)$ & $1.065(100.09)$ & +0.06 & +0.09 \\
\hline 0.305 & 1.276 & $0.305(100.00)$ & $1.277(100.08)$ & -0.06 & +0.07 \\
\hline
\end{tabular}

*Average of four determinations

\section{Results and Discussion}

The third order derivative spectra recorded for the various solutions containing different amounts of vanadium (V) or palladium (II) are shown in "Figure 3". The [Pd(II)-HNHBH] solution showed maximum amplitude at $472.5 \mathrm{~nm}$ where the $[\mathrm{V}(\mathrm{V})-\mathrm{HNHBH}]$ solution showed zero amplitude. Similarly in $[\mathrm{V}(\mathrm{V})$ HNHBH] species showed maximum amplitude at $509 \mathrm{~nm}$ where the Pd(II) complex showed zero amplitude. The simultaneous determination of $\mathrm{V}(\mathrm{V})$ and $\mathrm{Pd}(\mathrm{II})$ was carried out by measuring the third derivative amplitudes at $465.5 \mathrm{~nm}$ and $482.5 \mathrm{~nm}$ respectively. The plots constructed between the derivative amplitudes measured and the amount of $\mathrm{V}(\mathrm{V})$ or Pd(II) showed that the Beer's law was obeyed in the range $0.050-1.935$ $\mu \mathrm{g} \mathrm{mL}^{-1}$ of $\mathrm{V}(\mathrm{v})$ and $0.022-2.021 \mu \mathrm{g} \mathrm{mL}^{-1}$ of $\mathrm{Pd}(\mathrm{II})$ respectively. Since no amplitude was observed for $\mathrm{Pd}(\mathrm{II})$ complex at $482.5 \mathrm{~nm}$ where the $\mathrm{V}(\mathrm{V})$ complex showed maximum and no derivative amplitude by $\mathrm{V}(\mathrm{V})$ complex at $465.5 \mathrm{~nm}$ where the Pd(II) complex has maximum amplitude, the zero cross method was adopted for the simultaneous determination of $\mathrm{V}(\mathrm{V})$ and $\mathrm{Pd}(\mathrm{II})$ in the binary synthetic mixtures by measuring their derivative amplitudes $465.5 \mathrm{~nm}$ and $482.5 \mathrm{~nm}$ respectively. The results obtained along with recovery percentages are shown in "Table".1. The relative errors obtained in these determinations indicate the suitability of the proposed method for the simultaneous determination of $\mathrm{V}(\mathrm{V})$ and $\mathrm{Pd}(\mathrm{II})$. The study on the effect of diverse cations on the derivative amplitudes showed that $\mathrm{Tl}(\mathrm{III}), \mathrm{Pb}(\mathrm{II}), \mathrm{Cd}(\mathrm{II})$, and $\mathrm{Hg}$ (II) do not interfere in any levels., $\mathrm{Sn}$ (II), and $\mathrm{Zn}$ (II) were tolerable upto 5 fold excess. Y(III), $\mathrm{La}(\mathrm{III}), \mathrm{In}(\mathrm{III})$ and $\mathrm{Al}(\mathrm{III})$ interfered when present in more than equal amounts. 


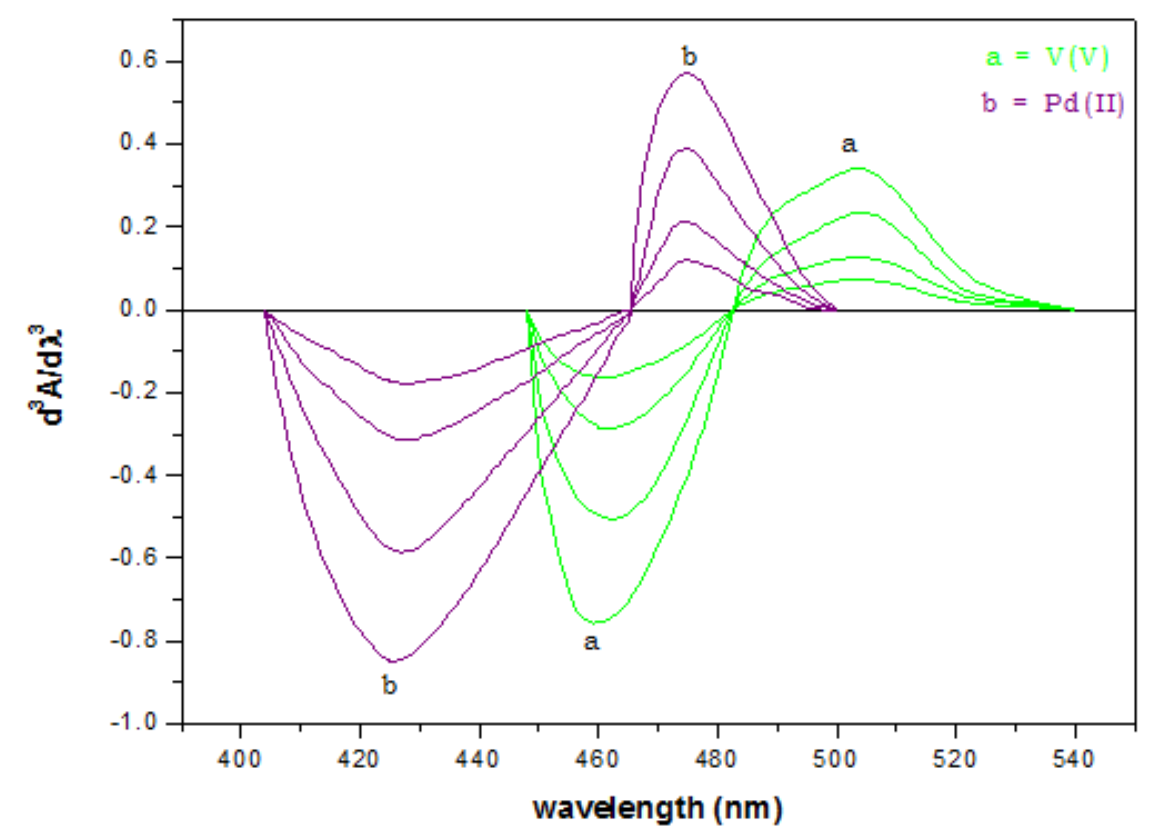

Fig. 3. Third order derivative spectra of (a) V(V) - HNAHBH and (b) Pd(II) - HNAHBH

\section{Applications}

$$
\begin{array}{ll}
\mathrm{V}(\mathrm{V})\left(\mu \mathrm{g} \mathrm{mL}^{-1}\right): & 0.203 ; 0.356 ; 0.661 ; 0.967 . \\
\mathrm{Pd}(\mathrm{II})\left(\mu \mathrm{g} \mathrm{mL}^{-1}\right): & 0.425 ; 0.744 ; 1.383 ; 2.021
\end{array}
$$

The proposed simultaneous method was applied for the determination of $\mathrm{V}(\mathrm{V})$ and $\mathrm{Pd}(\mathrm{II})$ in environmental, pharmaceutical and alloy samples.

\subsection{Plant sample}

\section{Preparation of sample solutions}

The raddish roots were washed thoroughly with water, wiped with filter paper and weighed. Then the samples were dried, ashed and brought into solution as per the standard procedures $[13,14]$ and neutralized with $\mathrm{NH}_{4} \mathrm{OH}$ solution. Since the sample did not contain any detectable levels vanadium or palladium, known amounts the metal ions were spiked into the resultant solution and finally diluted to known volume with distilled water. Suitable aliquot of the sample solution was analyzed according to the simultaneous procedure and the vanadium and palladium contents were determined. The results are presented in "Table. 2."

\subsection{Pharmaceutical sample solution}

$10 \mathrm{ml}$ of Neogadine Elixer syrup were treated with $10 \mathrm{ml}$ conc. $\mathrm{HNO}_{3}$ and the resultant mixture was evaporated to dryness. The residue was leached with $5 \mathrm{ml} 0.5 \mathrm{M} \mathrm{H}_{2} \mathrm{SO}_{4}$. The solution was neutralized with dilute $\mathrm{NH}_{3}$. As the sample did not contain known levels of palladium, a known aliquot of palladium solution containing fixed amount of palladium was introduced and finally the solution was made upto known volume with distilled water. Suitable volumes of the sample solution were analyzed by the proposed derivative method and the amounts of $\mathrm{V}(\mathrm{V})$ and $\mathrm{Pd}(\mathrm{II})$ present were calculated. The results are presented in "Table. 2."

\subsection{Water sample}

Known amounts of vanadium and palladium were spiked into mineral water and tap water and the resultant solutions were diluted to known volumes with distilled water. The sample solutions were analyzed using the proposed simultaneous derivative method and the vanadium and palladium contents were evaluated. The results are presented in "Table. 2."

\subsection{Alloy sample [15]}

Synthetic mixtures of Okay alloy and Palau alloy were prepared by mixing vanadium and palladium along with other associated metals as shown in "Table. 3." in suitable ratio and dissolved in $\mathrm{HCl}-\mathrm{HNO}_{3}$ mixture according to the standard procedure. The solution was filtered and finally diluted to known volume with distilled water. Known aliquots of sample solutions were treated with $400 \mu \mathrm{g}$ of EDTA (to mask Ni) and the vanadium and palladium contents were determined by the proposed simultaneous derivative method. The results along with the recovery percentages are given in "Table. 3." 
Table.2. Determination of $\mathrm{V}(\mathrm{V})$ and $\mathrm{Pd}(\mathrm{II})$ in plant, pharmaceutical and water samples

\begin{tabular}{|c|c|c|c|c|c|c|}
\hline \multirow[t]{2}{*}{ Sample } & \multicolumn{3}{|c|}{$\begin{array}{l}\text { Amount of vanadium } \\
\left(\mu \mathrm{g} \mathrm{mL} \mathrm{mL}^{-1}\right)\end{array}$} & \multicolumn{3}{|c|}{$\begin{array}{l}\text { Amount of palladium } \\
\left(\mu \mathrm{g} \mathrm{mL}^{-1}\right)\end{array}$} \\
\hline & Added & Found* & $\begin{array}{l}\text { Recovery } \\
\text { Percentage } \\
(\%)\end{array}$ & Added & Found* & $\begin{array}{l}\text { Recovery } \\
\text { Percentage } \\
(\%)\end{array}$ \\
\hline $\begin{array}{l}\text { Plant material } \\
\text { (raddish) }\end{array}$ & 5.0 & $5.01 \pm 0.04$ & 100.20 & 8.0 & $8.02 \pm 0.01$ & 100.25 \\
\hline \multirow{2}{*}{$\begin{array}{l}\text { Pharmaceutical } \\
\text { sample }^{\mathrm{a}}\end{array}$} & - & $5.24 \pm 0.06$ & 104.80 & 4.0 & $4.03 \pm 0.05$ & 100.75 \\
\hline & 5.0 & $10.32 \pm 0.03$ & 100.58 & 6.0 & $5.97 \pm 0.02$ & 99.50 \\
\hline Tap water & 10.0 & $10.25 \pm 0.03$ & 102.50 & 10 & $9.98 \pm 0.05$ & 99.80 \\
\hline mineral water & 5.0 & $4.96 \pm 0.08$ & 99.20 & 5.0 & $5.06 \pm 0.02$ & 101.20 \\
\hline
\end{tabular}

*Average of five determinations $\pm \mathrm{SD}$

$\mathrm{a}=$ Neogadine Elexer (Raptakos Brett \& Co. Ltd, India)

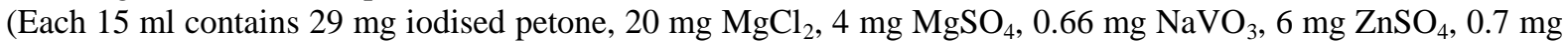
pridomine $\mathrm{HCl}, 0.5 \mathrm{mg}$ cyanocobalamine, $10 \mathrm{mg}$ nicotinamide, $0.95 \mathrm{ml}$ alcohol (95\%). Vanadium taken $5.26 \mu \mathrm{g}$ $\left.\mathrm{mL}^{-1}\right)$

Table.3. Determination of V(V) and Pd(II) in synthetic alloy samples

\begin{tabular}{|c|c|c|c|c|c|c|}
\hline \multirow{2}{*}{$\begin{array}{l}\text { Sample } \\
\& \\
\text { composition }\end{array}$} & \multicolumn{3}{|c|}{$\begin{array}{l}\text { Amount of vanadium } \\
\left(\mu \mathrm{g} \mathrm{mL}^{-1}\right)\end{array}$} & \multicolumn{3}{|c|}{$\begin{array}{l}\text { Amount of palladium } \\
\left(\mu \mathrm{g} \mathrm{mL}^{-1}\right)\end{array}$} \\
\hline & Taken & Found* & $\begin{array}{l}\text { Recovery } \\
\text { Percentage }(\%)\end{array}$ & Taken & Found* & $\begin{array}{l}\text { Recovery } \\
\text { Percentage (\%) }\end{array}$ \\
\hline $\begin{array}{l}\text { Oakay alloy } \\
\text { 18.2Pd;18.2Pt; } \\
54.2 \mathrm{Ni} ; 9.4 \mathrm{~V}(\%)\end{array}$ & 0.846 & $0.844 \pm 0.004$ & 99.76 & 1.468 & $\begin{array}{l}1.472 \quad \pm \\
0.002\end{array}$ & 100.27 \\
\hline $\begin{array}{l}\text { Palau alloy } \\
0.45 \mathrm{Ni} ; 0.15 \mathrm{Pt} ; \\
0.075 \mathrm{~V} ; 0.15 \mathrm{Pd} \\
(\mathrm{mg})\end{array}$ & 0.686 & $0.688 \pm 0.01$ & 100.29 & 1.980 & $\begin{array}{l}1.985 \\
0.009\end{array}$ & 100.25 \\
\hline
\end{tabular}

$*$ Average of four determinations \pm SD

\section{Conclusions}

The proposed third order derivative spectrophotometric method is simple, rapid, sensitive, and accurate without any type of extraction and does not require the solving of simultaneous equations. The applicability of the method in various samples have been studied which gave encouraging results in the simultaneous determination of $\mathrm{V}(\mathrm{V})$ and $\mathrm{Pd}(\mathrm{II})$ (table 2 and 3).

\section{Acknowledgements}

The authors thankful to Dr. B.V. Subbareddy, IICT Hyderabad for providing IR, NMR and mass spectral data. Authors also extend their sincere thanks to The Dept. of Chemistry, S.K. University, Ananatapur for the timely help and providing necessity facilities.

\section{References}

[1]. R. Sahu, S.M. Sondhi and B. Gupta, Talanta, 42(3), 1995, 401-405

[2]. J.Versieck, and R.Cornelis, Anal. Chim. Acta, , 116, 1980, 217.

[3]. G.D. Clayton and F.E.Calyton, Patty’s Industrial Hygiene and Toxicology, vol. 2A, 3rd Ed., Wiley New York, 1981 , P. 2013.

[4]. S.Langard, T. Norseth, L. Friberg, G.R.Nerberg, and V.B. Vouk, (Eds.), Hand Book on toxicology of metals, Elsevier, Amserdam, 1986.

[5]. B.Venugopal and T.D Luckey, Metal Toxicity in Mammals 2, plenum press, New York, 1979, P. 220.

[6]. A.Safavi, M.R. Hormozi Nezhad, and E.Shams, Anal Chim. Acta, 409, 2000, 283.

[7]. S. Caroli, A. Alimonti, F. Petrucci, B. Bocca, M. Krachler, F. Forastere, M T Sacerdote and S. mallone Spectro chim acta Part B., 56(7), 2001, 1241.

[8]. P. Govinda Chowdary and V. Saleem Basha. Der Pharma Chemica, 7(12), 2015, 338-345

[9]. P. Govinda Chowdary and V. Saleem Basha, WJPR, 4(5), 2015, 1168-1180

[10]. Brown, E.V., Caglioti, L., Paoluca, G., Sucrow, W., Hydrazones and hydrazones, In: Methodicum chemicum, C-N compounds, Academic Press, New York, 6. 1975

[11]. A.Ali Ensafi, M.K. Amini, and M. Mazloum, Anal. Lett, 32, 1999, 1927

[12]. K.Gavazov and A.Alexandrov, Talanta, 52, 2000, 539

[13]. S.A.Abbasi, Anal. Lett. 20, 1987, 1347.

[14]. D.Glick (Ed.), Methods of Biological Analysis, vol. 21, John Wiley, 1973, p.39

[15]. W. Yang, Q. Hu, Z. Huang, J. Yin, G. Xie and J. Chen, J.Serb.Chem.Soc, 71(7), 2006, 821-828. 